\title{
Preferência pela Liquidez do Setor Bancário no Ciclo de Expansão do Crédito no Brasil: 2003-2010
}

\section{Liquidity Preference of Banking Sector during the Cycle of Credit Expansion in Brazil: 2003-2010}

Resumo: Este trabalho pretende mostrar que, durante o ciclo de expansão de crédito ocorrido na economia brasileira entre os anos de 2003 e 2010, os bancos públicos atuaram com grau de preferência pela liquidez superior à dos bancos privados até a eclosão da crise financeira internacional. A necessidade de obtenção de resultados econômico-financeiros por parte dos bancos públicos teria norteado a sua atuação e imposto restrições ao longo de todo o período.

Palavras-chave: Bancos públicos. Bancos privados. Crédito. Economia brasileira.

Abstract: This study aims to show that during the cycle of credit expansion occurred in the Brazilian economy between 2003 and 2010, public banks had acted with a degree of liquidity preference higher than that of private banks until the international financial crisis. The need to achieve economic and financial results by public banks have guided and restricted his actions over the whole period.

Keywords: Public banks. Private banks. Credit. Brazilian economy.

JEL Classification: G21; E44.

\section{1 lntrodução}

Um dos fatos mais notáveis do ciclo de expansão econômica ocorrido no Brasil no período 2004-2007 foi a expansão sem precedentes do crédito bancário. A relação crédito/Produto Interno Bruto (PIB) saiu de um patamar médio de $25 \%$ em 2003 para 47\% em julho de 2011. As principais causas para este fenômeno podem ser sumarizadas em três fatores:

Professor Adjunto da Faculdade de Economia da Universidade Federal Fluminense (UFF). E-mail: victor_araujo@terra.com.br. O autor agradece as sugestões feitas por um parecerista anônimo, mas assume a responsabilidade por eventuais erros e emissões. 
a) a criação do crédito consignado em folha de pagamento no ano de 2003, que teria expandido o crédito às pessoas físicas;

b) a redução da taxa básica de juros Selic, que teria reduzido as receitas com operações envolvendo títulos públicos realizadas pelos bancos e induzido estes últimos a expandir suas operações de crédito; $\mathrm{e}$

c) o ambiente macroeconômico favorável, seja pelo aceno, por parte do governo que assume em janeiro de 2003, com uma política macroeconômica market friendly, seja pelo cenário externo de expansão do comércio exterior, seja também pelas políticas de melhoria da renda dos segmentos mais pobres da população brasileira. ${ }^{1}$

A despeito do ciclo expansivo do crédito ser comumente atribuído a políticas implementadas pelo governo brasileiro, chama a atenção que o mesmo tenha sido induzido pelos bancos privados: de fato, o crédito oriundo dos bancos públicos somente se expande a taxas mais expressivas com certo retardo, praticamente dois anos depois de iniciado o ciclo. Não obstante a importância dos bancos públicos na qualidade do crédito ofertado, ${ }^{2}$ o volume de crédito oriundo dessas instituições demorou a responder ao ciclo expansivo do crédito. Somente depois da eclosão da crise financeira internacional de 2008-2009 é que a situação se inverte: a ação anticíclica implementada pelos bancos públicos federais fez com que as operações de crédito dos bancos públicos se expandisse a taxas mais elevadas do que a dos bancos privados.

O instrumental teórico pós-keynesiano é útil para explicar esse comportamento. Do ponto de vista do conjunto do sistema bancário brasileiro, é possível afirmar que as três causas apontadas anteriormente para explicar a expansão da oferta de crédito atuaram de forma a reduzir o grau de preferência pela liquidez dos bancos, induzindo-os a recompor suas carteiras de ativos, nas quais as operações de crédito tiveram um espaço maior em detrimento das operações com títulos e valores mobiliários. Já do ponto de vista dos dois subconjuntos que compõem o setor bancário, bancos públicos e privados, esses fatores exerceram maior influência sobre esses últimos. Ou seja, os bancos públicos operaram, até a eclosão da crise financeira, com grau de preferência pela liquidez superior ao dos bancos privados.

1 Ver, a este respeito: Freitas e Prates (2009), Prates e Biancareli (2009), Sant'anna, Borça Junior e Araujo (2009).

2 Por exemplo, o Banco do Brasil (BB) constitui o mais importante provedor de crédito rural; a Caixa Econômica Federal (CEF), o mais importante financiador no setor imobiliário; e o Banco Nacional de Desenvolvimento Econômico e Social (BNDES), o mais importante provedor de recursos a longo prazo. 
Este trabalho tem por objetivo identificar o padrão de atuação do setor bancário no ciclo de crédito mais recente, com um olhar particular sobre a desagregação desse setor entre os bancos públicos e privados a partir de indicadores que procuram captar o grau de preferência pela liquidez dessas instituições - assumindo, portanto, um referencial teórico pós-keynesiano. Para tanto, está organizado em cinco seções, a contar com a presente introdução. A seção 2 aborda de forma sucinta os conceitos, a partir do referencial teórico pós-keynesiano, que serão utilizados ao longo deste trabalho. A seção 3 procura caracterizar o ciclo de expansão de crédito a partir de fatos estilizados. A seção 4 analisa a atuação dos bancos públicos e privados a partir daquela caracterização inicial. A seção 5 apresenta as considerações finais.

\section{Incerteza e Preferência pela Liquidez dos Bancos: uma Aproximação Teórica}

A relação entre sistema bancário e desempenho macroeconômico é alvo de intensa controvérsia na teoria econômica. Uma das formas possíveis de se apresentar esse debate ${ }^{3}$ é contrapor as abordagens segundo as quais o setor bancário atua de forma neutra, como mero intermediador de recursos entre poupadores e despoupadores, àquelas segundo as quais o comportamento dos bancos, ao longo do processo de criação de moeda escritural, afeta o desempenho do setor "real" da economia.

As abordagens derivadas dos modelos Gurley e Shaw (1955), Shaw (1973) e McKinnon (1973) fazem parte do primeiro grupo. Segundo essa concepção, o mercado financeiro possui o papel de transferir recursos entre unidades superavitárias (poupadoras) e deficitárias (despoupadoras), e a taxa de juros deve ser flexível o suficiente para equilibrar oferta e demanda por recursos de empréstimo. Esses modelos formam o corpo básico da teoria da liberalização dos mercados financeiros: quaisquer formas de intervenção sobre esses mercados, particularmente através da introdução de bancos públicos, geram resultados ineficientes, porque produzem taxas de juros abaixo da de equilíbrio, produzindo baixos níveis de poupança e de investimento.

O contraponto a essa visão é oferecido, na macroeconomia moderna, pelas teorias das falhas de mercado e pela teoria pós-keynesiana.

O ponto de partida das abordagens das falhas de mercado é a crítica a duas das premissas implícitas na teoria dos fundos emprestáveis e que são imprescindíveis para que a taxa de juros convirja para o equilíbrio: existência de informação

3 Não temos aqui a intenção de esgotar o debate, nem de resenhar de forma exaustiva as diferentes concepções a este respeito, mas tão somente oferecer uma aproximação teórica, em particular sobre o uso do conceito de preferência pela liquidez, que constitui peça fundamental deste artigo. 
simétrica e de mercados completos. Segundo Stiglitz e Weiss (1981), a hipótese de existência de informação simétrica é violada nos mercados financeiros: o tomador de empréstimos possui informações melhores do que o emprestador sobre o risco e o retorno potencial do projeto para o qual está solicitando o empréstimo. O resultado é o racionamento de crédito: os emprestadores se recusam a emprestar mesmo que o tomador esteja disposto a pagar juros mais altos. O excesso de demanda por crédito não se traduz em aumento das taxas de juros - ou seja, os preços não aumentam para eliminar o excesso de demanda.

Outro tipo específico de falha de mercados que pode ser observada nos países em desenvolvimento constitui aquilo que se convencionou chamar de incompletude dos mercados. Segundo Stiglitz (1993), em economias menos desenvolvidas os mercados financeiros são incompletos: os mercados de capitais são fracos e os mercados acionários, muitas vezes, inexistem. Os bancos, por sua vez, tendem a privilegiar os empréstimos de curto prazo. Haveria, por parte do setor privado, um desinteresse em financiar projetos que, embora tenham um alto retorno social, têm um baixo retorno privado e alto risco. Esta abordagem prevê a intervenção do Estado no mercado financeiro, particularmente através da atuação de bancos públicos, a quem caberia "[...] alocar crédito para setores e segmentos não adequadamente atendidos pelo mercado" (DEOS; MENDONÇA, 2010, p. 58).

É importante ressaltar que ambas as abordagens anteriores assumem a primazia dos mercados financeiros: mesmo na abordagem das falhas de mercado, $s e$ estas não existissem, valeriam os resultados previstos na teoria dos fundos emprestáveis. Por esta razão, ambas as abordagens podem ser consideradas convencionais, diferentemente da abordagem pós-keynesiana.

Esta, por sua vez, tem como ponto de partida o princípio da demanda efetiva (PDE) como explicativo da dinâmica macroeconômica. Segundo o PDE, os níveis de emprego e de renda da economia dependem dos gastos autônomos em investimento. O consumo induzido amplia esse impulso autônomo por meio do multiplicador. Essa abordagem inverte, então, a causalidade da poupança para o investimento, presente na abordagem convencional, de investimento para a poupança (KEYNES, 1936). O investimento, segundo os keynesianos, depende das decisões dos empresários, tendo por base o retorno esperado dos ativos de capital. O financiamento do investimento, em um sistema de moeda fiduciária no qual os bancos têm a prerrogativa de criar moeda escritural (a partir de uma operação meramente contábil) depende da disposição dos bancos em mobilizar os recursos iniciais para o empresário financiar o investimento.

$\mathrm{Na}$ teoria pós-keynesiana, os conceitos fundamentais para entender o comportamento da firma bancária são o de preferência pela liquidez e incerteza. A teoria da preferência pela liquidez formulada por Keynes ${ }^{4}$ é comumente enten-

$4 \quad$ Ver, por exemplo, Keynes (1936). 
dida como uma teoria da demanda por moeda a partir dos motivos transação, precaução, especulação e finance. Entretanto, mais do que uma teoria da demanda por moeda, esta abordagem constitui, na verdade, uma teoria de escolha de ativos na qual os agentes econômicos levam em consideração os retornos esperados das diferentes classes de ativos vis-à-vis o atributo de liquidez de cada uma delas (CARVALHO, 2007). A explicação pela qual os agentes optam por constituir seus portfólios com ativos menos rentáveis, porém mais líquidos, é a conveniência e a segurança potencial, atributos geralmente associados à flexibilidade que esses ativos oferecem ao permitir a recomposição das estratégias sob diferentes cenários. Os bancos, como quaisquer outros agentes econômicos, também possuem preferência pela liquidez e, como tal, também constituem seus portfólios “[...] de modo a conciliar lucratividade e escala de preferência pela liquidez" (PAULA, 1999, p. 173).

O sistema financeiro produz e negocia direitos sobre renda futura, cujas estimativas envolvem risco, incerteza e graus variados de confiança nos cenários formulados (HERMANN, 2009). Em cenários de maior incerteza, a defesa natural dos bancos é reorientar seus portfólios a favor de ativos com maior grau de liquidez, abrindo mão da maior rentabilidade oferecida pelos ativos menos líquidos e reduzindo a oferta de crédito. Ao contrário, sob expectativas otimistas, os bancos tendem a privilegiar rentabilidade sobre liquidez, elevando a participação das operações de maior risco em seus ativos (PAULA, 1999).

Mas a função de preferência pela liquidez dos bancos não se restringe ao seu ativo: ao fazer a opção por uma carteira de ativos mais favorável a operações de crédito de prazo mais longo, ou por uma carteira em que predominem ativos financeiros, a natureza das obrigações emitidas pelo banco deve ser adequada aos prazos e riscos dos seus ativos. Por exemplo, operações de crédito de prazo mais longo não devem ter como contrapartida operações passivas de prazo mais curto, como depósitos à vista. Em outras palavras, o banco deve gerir o seu balanço "[...] com base na escolha entre quanto e quais tipos de ativos comprar e quanto e quais tipos de obrigações emitir" (OLIVEIRA, 2006, p. 3). É neste sentido que Carvalho (2007, p. 15) afirma que é possível "ler" a preferência pela liquidez de cada banco em seu balanço: ela exerce influência sobre a escolha das classes de ativos que os bancos irão incorporar, assim como sobre o tipo e o prazo de obrigações que deverão emitir.

Com efeito, é inerente à atuação dos bancos um comportamento pró-cíclico: em períodos de expansão econômica essas instituições tendem a expandir suas operações de crédito, ao passo que em períodos de contração econômica ou de maior incerteza, os bancos tendem a privilegiar ativos mais líquidos e de prazo mais curto em lugar das operações de crédito. 
Sob esta perspectiva, é possível afirmar que o arcabouço keynesiano contempla um espaço importante para atuação dos bancos públicos: a ação anticíclica, expandindo as operações de crédito nos momentos de reversão do estado de confiança da economia e contra-arrestando, total ou parcialmente, a contração do crédito resultante da deterioração das expectativas. Neste caso, os bancos públicos não constituem uma solução do tipo second best, tal como ocorre nas abordagens de falhas de mercado, mas podem atuar no mesmo nível hierárquico dos bancos privados, de forma complementar ou mesmo com atribuições específicas, e sempre exercendo papel primordial nas economias capitalistas. ${ }^{5}$

É a partir deste referencial teórico que tentaremos compreender o ciclo recente de expansão do crédito em curso na economia brasileira desde 2004. Pelo uso de indicadores calculados a partir de contas do ativo e do passivo dos bancos tentaremos mostrar como evoluiu o grau de preferência pela liquidez dessas instituições. Além disso, desagregando o sistema bancário brasileiro a partir do controle da propriedade do capital dos bancos, será possível identificar diferentes padrões de preferência pela liquidez, dos bancos privados e dos bancos públicos.

A próxima seção irá caracterizar o ciclo de expansão recente de crédito, ao passo que a seção seguinte analisará os indicadores de preferência pela liquidez.

\section{Caracterização do Ciclo de Expansão do Crédito}

O primeiro fato estilizado do ciclo de expansão de crédito foi a notável expansão da relação crédito/PIB, que sai de patamares em torno de $24 \%$ em 2003/4 para 46\% em novembro de 2010, conforme apontado pelo Gráfico 1.

$5 \quad$ Além da função anticíclica, o arcabouço keynesiano também oferece espaço de atuação dos bancos públicos em outras duas funções. Por exemplo, a incerteza existente nas regiões periféricas pode condicionar os bancos a operarem nessas regiões com maior grau de preferência pela liquidez; a incerteza existente nos projetos de investimento de prazo mais longo pode induzir os bancos a atuarem com um grau de preferência pela liquidez que simplesmente inviabilize o financiamento de longo prazo. Assim, bancos públicos podem atuar no desenvolvimento regional e no financiamento de longo prazo. 
Gráfico 1 - Brasil: relação crédito/PIB (\%) - 2001 a 2010

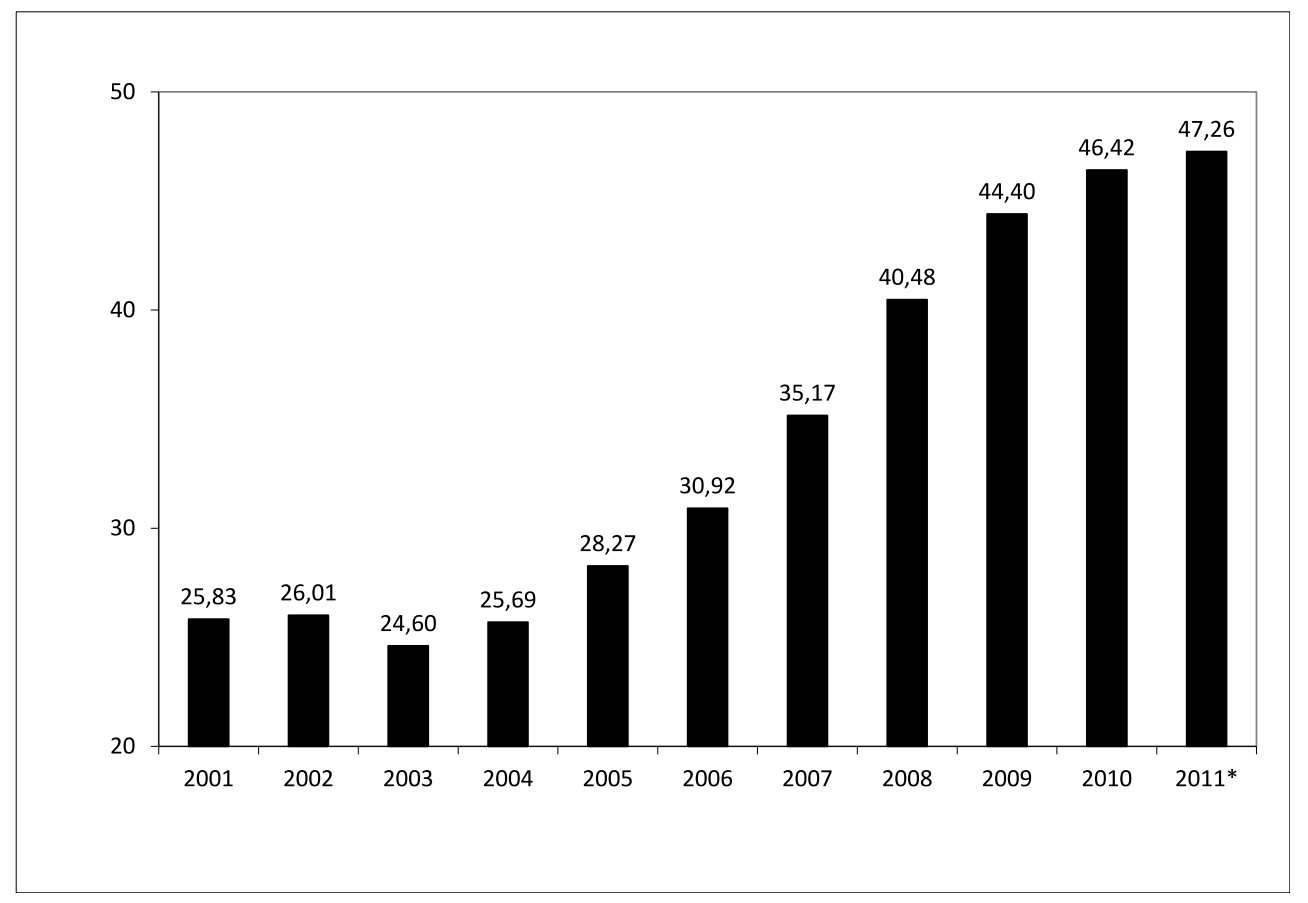

Fonte: Elaboração própria a partir de dados do Banco Central do Brasil.

O segundo fato estilizado é que o ciclo foi induzido pelos bancos privados, os quais expandiram o volume das operações de crédito a taxas superiores à dos bancos públicos durante todo o ciclo até a eclosão da crise financeira de 2008-9, data a partir da qual a situação se inverteu (Gráfico 2).

Gráfico 2 - Crédito total, taxa de crescimento real por propriedade do capital - 20032010

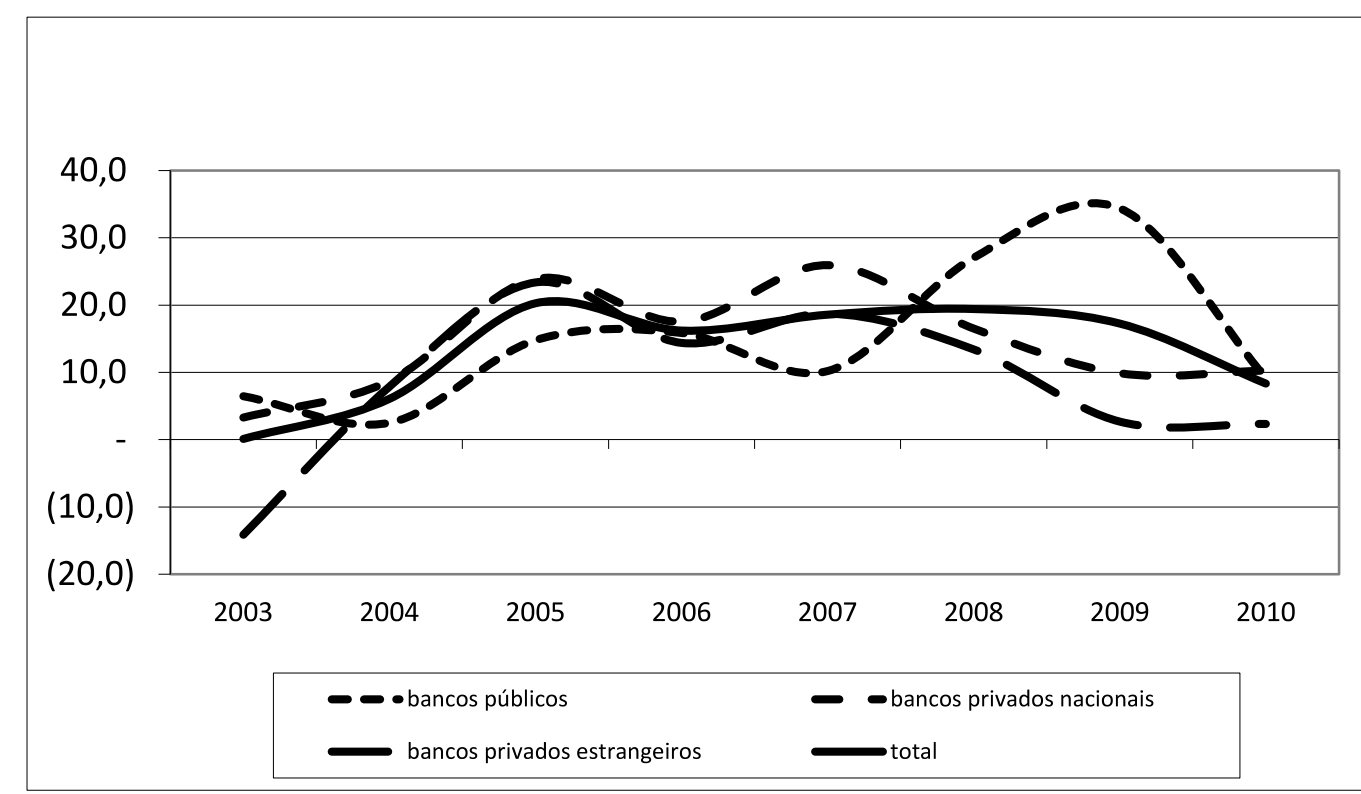

Fonte: Elaboração própria a partir de dados do Banco Central do Brasil, deflacionados pelo IGP-M. 
Quando os dados de expansão do estoque de crédito por propriedade de capital são abertos por setor de atividade, é possível perceber que os bancos privados, de propriedade privada ou estrangeira, estiveram à frente durante os anos iniciais do ciclo nos setores industrial, rural, comercial e de pessoas físicas, ao passo que os bancos públicos lideraram apenas o crédito habitacional (Tabela 1). A priori, os dados parecem sugerir que o ciclo expansivo de crédito não teve origem na indução direta dos bancos públicos. Ainda assim, boa parte da literatura econômica parece sugerir que, não obstante os bancos privados terem liderado o ciclo expansivo durante a maior parte do tempo até a crise financeira internacional de 2008/9, isto ocorreu devido à execução de políticas públicas que teriam induzido este novo padrão de comportamento por parte dos bancos privados.

As principais medidas adotadas pelo governo brasileiro neste sentido teriam sido:

a) a introdução do crédito consignado em folha de pagamento, no ano de 2003;

b) a redução da taxa básica de juros Selic a partir de 2004; e

c) a garantia de um ambiente macroeconômico favorável.

Tabela 1 - Taxa de crescimento real do estoque de crédito por setor e por controle de capital - 2003-2011

\begin{tabular}{llllllll}
\hline \multicolumn{7}{c}{ Bancos Públicos } \\
\hline & $\begin{array}{l}\text { Indús- } \\
\text { tria }\end{array}$ & $\begin{array}{l}\text { Habita- } \\
\text { ção }\end{array}$ & Rural & Comércio & $\begin{array}{l}\text { Pessoas } \\
\text { físicas }\end{array}$ & $\begin{array}{l}\text { Outros } \\
\text { serviços }\end{array}$ & Total \\
\hline 2003 & $(6,73)$ & $(2,54)$ & 28,11 & 5,40 & 1,34 & 23,90 & 6,46 \\
2004 & $(8,57)$ & $(6,27)$ & 5,43 & 12,07 & 12,83 & 9,10 & 2,51 \\
2005 & 9,37 & 14,82 & 14,59 & 15,43 & 21,81 & 25,23 & 14,79 \\
2006 & 17,62 & 23,73 & 12,26 & 18,95 & 16,81 & 21,69 & 15,86 \\
2007 & 14,48 & 15,86 & 1,61 & 18,96 & 18,57 & 4,77 & 10,20 \\
2008 & 30,35 & 24,56 & 10,46 & 21,16 & 25,85 & 36,71 & 27,04 \\
2009 & 20,43 & 54,21 & 9,49 & 25,08 & 39,08 & 31,39 & 34,37 \\
2010 & 9,19 & 37,95 & $(5,18)$ & 10,98 & 8,22 & 2,45 & 9,15 \\
$2011^{*}$ & 3,25 & 20,78 & 1,47 & 2,64 & 7,47 & 3,47 & 5,98 \\
\hline Média & 9,28 & 19,08 & 8,33 & 14,30 & 16,41 & 17,01 & 13,63 \\
anual & & & & & & & \\
\hline
\end{tabular}

\begin{tabular}{llllllll}
\hline \multicolumn{7}{c}{ Bancos Privados Nacionais } \\
\hline & $\begin{array}{l}\text { Indús- } \\
\text { tria }\end{array}$ & $\begin{array}{l}\text { Habita- } \\
\text { ção }\end{array}$ & Rural & Comércio & $\begin{array}{l}\text { Pessoas } \\
\text { fisicas }\end{array}$ & $\begin{array}{l}\text { Outros } \\
\text { serviços }\end{array}$ & Total \\
\hline 2003 & 4,38 & $(9,62)$ & 9,88 & 1,12 & 13,35 & $(7,25)$ & 3,29 \\
2004 & 0,04 & $(15,76)$ & 19,64 & 5,71 & 28,68 & $(9,94)$ & 8,73 \\
2005 & 11,10 & 0,54 & 5,88 & 20,68 & 45,58 & 9,15 & 23,90 \\
\hline
\end{tabular}


conclusão..

\begin{tabular}{llllllll}
\hline \multicolumn{7}{c}{ Bancos Privados Nacionais } \\
\hline & $\begin{array}{l}\text { Indús- } \\
\text { tria }\end{array}$ & $\begin{array}{l}\text { Habita- } \\
\text { ção }\end{array}$ & Rural & Comércio & $\begin{array}{l}\text { Pessoas } \\
\text { físicas }\end{array}$ & $\begin{array}{l}\text { Outros } \\
\text { serviços }\end{array}$ & Total \\
\hline 2006 & 15,25 & 11,06 & 19,14 & 24,21 & 17,66 & 19,55 & 17,54 \\
2007 & 25,11 & 10,78 & 14,77 & 21,46 & 28,01 & 35,06 & 25,94 \\
2008 & 23,34 & 27,51 & 9,76 & 10,91 & 12,74 & 24,13 & 16,51 \\
2009 & $(3,35)$ & 29,70 & 8,76 & 11,46 & 19,89 & 1,34 & 9,87 \\
2010 & 5,56 & 35,19 & 10,39 & 19,33 & 7,78 & 14,51 & 10,26 \\
$2011^{*}$ & 5,46 & 26,21 & 2,16 & 5,29 & 4,01 & 7,36 & 5,44 \\
\hline Média & 9,27 & 11,47 & 11,02 & 13,08 & 19,17 & 9,57 & 13,25 \\
anual & & & & & & & \\
\hline
\end{tabular}

Bancos Privados Estrangeiros

\begin{tabular}{llllllll}
\hline & $\begin{array}{l}\text { Indús- } \\
\text { tria }\end{array}$ & $\begin{array}{l}\text { Habita- } \\
\text { ção }\end{array}$ & Rural & Comércio & $\begin{array}{l}\text { Pessoas } \\
\text { fisicas }\end{array}$ & $\begin{array}{l}\text { Outros } \\
\text { serviços }\end{array}$ & Total \\
\hline 2003 & $(24,83)$ & $(13,53)$ & 41,48 & $(9,22)$ & $(9,13)$ & $(25,64)$ & $(14,14)$ \\
2004 & $(7,18)$ & $(7,30)$ & 13,35 & 23,20 & 19,83 & $(5,52)$ & 7,88 \\
2005 & 9,14 & 11,06 & 8,74 & 11,58 & 31,32 & 50,71 & 23,37 \\
2006 & 3,83 & $(5,91)$ & 9,36 & 6,00 & 27,83 & 8,67 & 14,38 \\
2007 & 24,54 & 65,20 & 12,00 & 3,41 & 18,94 & 23,64 & 18,73 \\
2008 & 24,13 & 29,78 & 0,51 & 22,38 & 5,25 & 19,74 & 13,41 \\
2009 & $(13,62)$ & 34,13 & $(2,62)$ & $(2,00)$ & 9,52 & 6,25 & 2,68 \\
2010 & $(0,31)$ & 21,47 & $(5,00)$ & 6,23 & 2,70 & $(0,17)$ & 2,33 \\
$2011^{*}$ & 3,09 & 17,23 & $(4,40)$ & 14,31 & 3,56 & 0,53 & 4,57 \\
\hline Média & 0,91 & 14,68 & 7,38 & 7,96 & 11,51 & 6,86 & 7,60 \\
anual & & & & & & & \\
\hline
\end{tabular}

\begin{tabular}{llllllll}
\hline & \multicolumn{7}{c}{ Total SFN } \\
\hline & $\begin{array}{l}\text { Indús- } \\
\text { tria }\end{array}$ & $\begin{array}{l}\text { Habita- } \\
\text { ção }\end{array}$ & Rural & Comércio & $\begin{array}{l}\text { Pessoas } \\
\text { físicas }\end{array}$ & $\begin{array}{l}\text { Outros } \\
\text { serviços }\end{array}$ & Total \\
\hline 2003 & $(7,28)$ & $(5,47)$ & 25,29 & $(1,44)$ & 3,23 & $(2,68)$ & 0,11 \\
2004 & $(5,01)$ & $(8,49)$ & 10,03 & 12,62 & 22,61 & $(1,87)$ & 6,06 \\
2005 & 10,03 & 11,49 & 11,40 & 16,38 & 36,71 & 23,72 & 20,27 \\
2006 & 14,06 & 18,18 & 13,41 & 17,07 & 20,28 & 17,98 & 16,21 \\
2007 & 20,57 & 19,24 & 6,59 & 15,55 & 23,72 & 19,35 & 18,58 \\
2008 & 26,26 & 25,66 & 8,58 & 16,39 & 12,85 & 28,02 & 19,42 \\
2009 & 4,59 & 47,74 & 7,42 & 11,12 & 20,80 & 14,72 & 17,25 \\
2010 & 6,43 & 35,69 & $(0,89)$ & 13,78 & 6,67 & 6,05 & 8,34 \\
$2011^{*}$ & 4,07 & 21,20 & 0,88 & 6,63 & 4,66 & 4,37 & 5,51 \\
\hline Média & 7,70 & 17,13 & 8,96 & 11,86 & 16,39 & 11,69 & 12,19 \\
anual & & & & & & & \\
\hline
\end{tabular}

Fonte: Elaboração própria a partir de dados do Banco Central do Brasil.

Nota: * julho. 
O crédito consignado em folha de pagamento foi instituído no ano de 2003 pela Medida Provisória 130, de setembro de 2003, convertida na Lei $\mathrm{n}^{\circ} 10.820$ de dezembro do mesmo ano, e consiste no desconto das parcelas do empréstimo na folha de pagamento. O menor risco inerente a este tipo de operação permitiria taxas de juros inferiores às que vigoravam, e era reforçado pela consignação das verbas rescisórias em caso de demissão dos trabalhadores regidos pela Consolidação das Leis Trabalhistas (CLT). ${ }^{6}$ A medida constituiu a mais importante adotada pelo governo brasileiro no sentido de estimular a expansão do crédito. ${ }^{7}$ É importante ressaltar que para as instituições financeiras, o crédito pessoal é mais fácil de ser avaliado do que o crédito corporativo, o qual exige "[...] maior conhecimento dos negócios, análise financeira e monitoramento das atividades empresariais" (FREITAS; PRATES, 2009, p. 216).

O impacto do crédito consignado pode ser observado a partir da Tabela 1: o crédito às pessoas físicas passa a crescer anualmente, já a partir do ano seguinte, à taxa acima de $22 \%$ em termos reais, bastante superior a todos os demais segmentos. Entre 2003 e 2010, o crédito a esta modalidade cresceu à taxa média de $17 \%$ a.a., cinco pontos percentuais acima da média do total do Sistema Financeiro Nacional (SFN), de 12\% a.a. Segundo o Gráfico 3, o crédito às pessoas físicas, que em dezembro de 2003 representava $24 \%$ do saldo das operações de crédito ao setor privado, passa a 33\% em novembro de 2010.

Gráfico 3 - Crédito ao setor privado: distribuição \% do saldo das operações por atividade econômica - 2003 e 2010

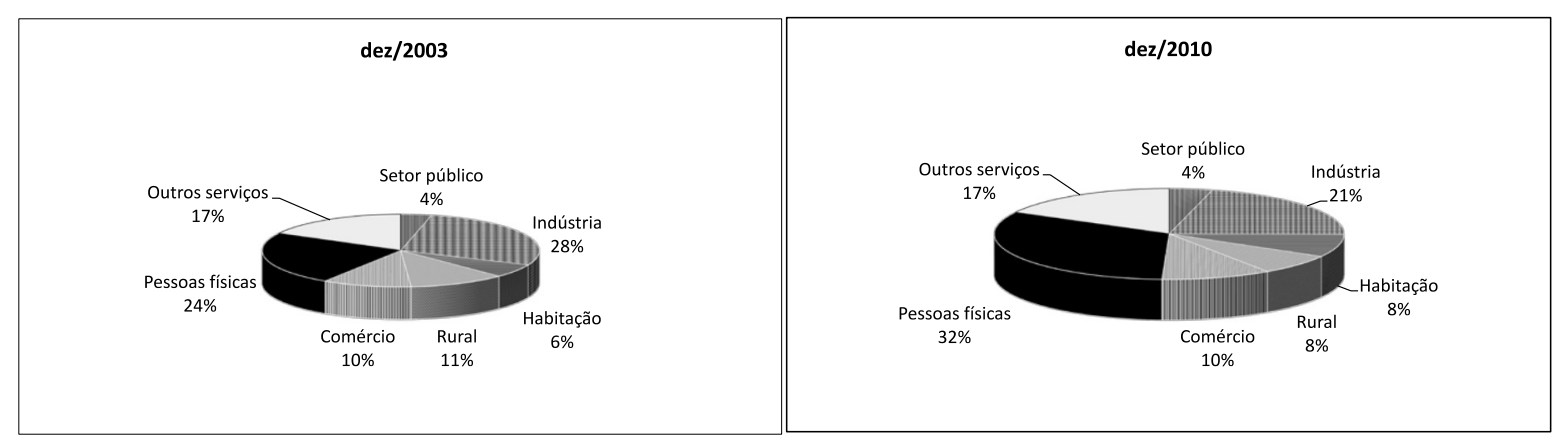

Fonte: Elaboração própria a partir de dados do Banco Central do Brasil.

Evidentemente, embora seja salutar reconhecer o impacto do crédito consignado na explicação do ciclo de expansão de crédito, os dados da Tabela 1

6 Segundo Barros, Fagundes e Cavalcante (2007), a disseminação de correspondentes bancários por meio dos quais boa parte das operações de crédito consignado era realizada teria contribuído para elevar o estoque de crédito nesta modalidade. Por outro lado, o pagamento de comissões a esses correspondentes bancários acabava por onerar essas operações, o que explicaria parcialmente o porquê do spread do crédito consignado ainda ser bastante elevado não obstante o menor risco inerente a ele.

7 Caetité, Strachman e Costa (2009, p. 16) afirmam que "[...] afora o crédito consignado, que teve impactos significativos no crescimento do crédito pessoal, não foram adotadas políticas de crédito de grande vulto que justifiquem o crescimento do volume total de crédito após 2004". 
mostram que durante o ciclo o crédito sofreu expansão significativa em todas as modalidades, ainda que em velocidades distintas. Desse modo, é lícito afirmar que o crédito consignado não pode ser apontado como a única causa do ciclo expansivo de crédito.

Argumento constantemente utilizado para explicar a expansão recente do crédito no Brasil é o ambiente macroeconômico. Segundo Freitas e Prates (2009, p. 216), a garantia dada no início do governo que assumiu em 2003 de que não haveria alteração na política macroeconômica, associada a um cenário internacional favorável - tanto em termos de comércio exterior como de liquidez para os países emergentes - teriam induzido os bancos a "[...] redefinir suas estratégias operacionais, priorizando a expansão do crédito", sobretudo, em um contexto de redução da taxa de juros Selic.

As expectativas otimistas de recuperação do emprego e da renda teriam reforçado o cenário propício à expansão não somente do crédito às famílias, mas também do crédito corporativo. O crédito industrial, que respondia, no início do ciclo, por $28 \%$ do saldo das operações de crédito, passa a crescer a taxas crescentes acima de dois dígitos a partir do ano de 2005, desacelerando somente após a eclosão da crise financeira de $2008-9,{ }^{8}$ condizente com o ritmo de crescimento da atividade industrial registrado no período. O crédito rural também sofreu expansão significativa nos anos de 2005 e 2006, estimulado pelo crescimento do agronegócio em contexto de elevação dos preços internacionais das commodities agrícolas. O crescimento do PIB brasileiro a partir de 2004, ainda que a taxas modestas, também está associado à explicação para a expansão do crédito nas modalidades de comércio e outros serviços. $\mathrm{O}$ crescimento da renda inerente a este movimento também explica a expansão do crédito habitacional, a qual deve ser acrescida de ação deliberada da Caixa Econômica Federal (CEF), principal instituição a atuar no setor de crédito imobiliário no País.

Parte integrante do ambiente macroeconômico enquanto indutor da redefinição da estratégia dos bancos em favor da expansão das operações de crédito foi a redução da taxa básica de juros Selic ocorrida a partir de meados de 2003. Não obstante a queda da taxa de juros não ter sido contínua - interrompida por dois ciclos de alta, o primeiro deles iniciado em setembro de 2004 e finalizado um ano depois; e o segundo iniciado em abril de 2008 e finalizado em janeiro de 2009 - a sua redução, em termos absolutos, teria levado a redução das receitas dos bancos com operações de títulos e valores mobiliários (TVM) e, assim, induzido a uma recomposição de suas carteiras de ativos em favor das operações de crédito. $\mathrm{O}$ Gráfico 4 evidencia esta relação: entre 2002 e 2004 as receitas obtidas pelo sistema bancário brasileiro através de operações com TVM caem consideravelmente, dando lugar para o aumento com receitas de operações de crédito.

8 Para mais detalhes sobre o crédito industrial entre o período 2003-9, ver Prates (2009). 
Gráfico 4 - SFN: receitas de intermediação financeira com operações de crédito e arrendamento mercantil e TVM, R \$ mil

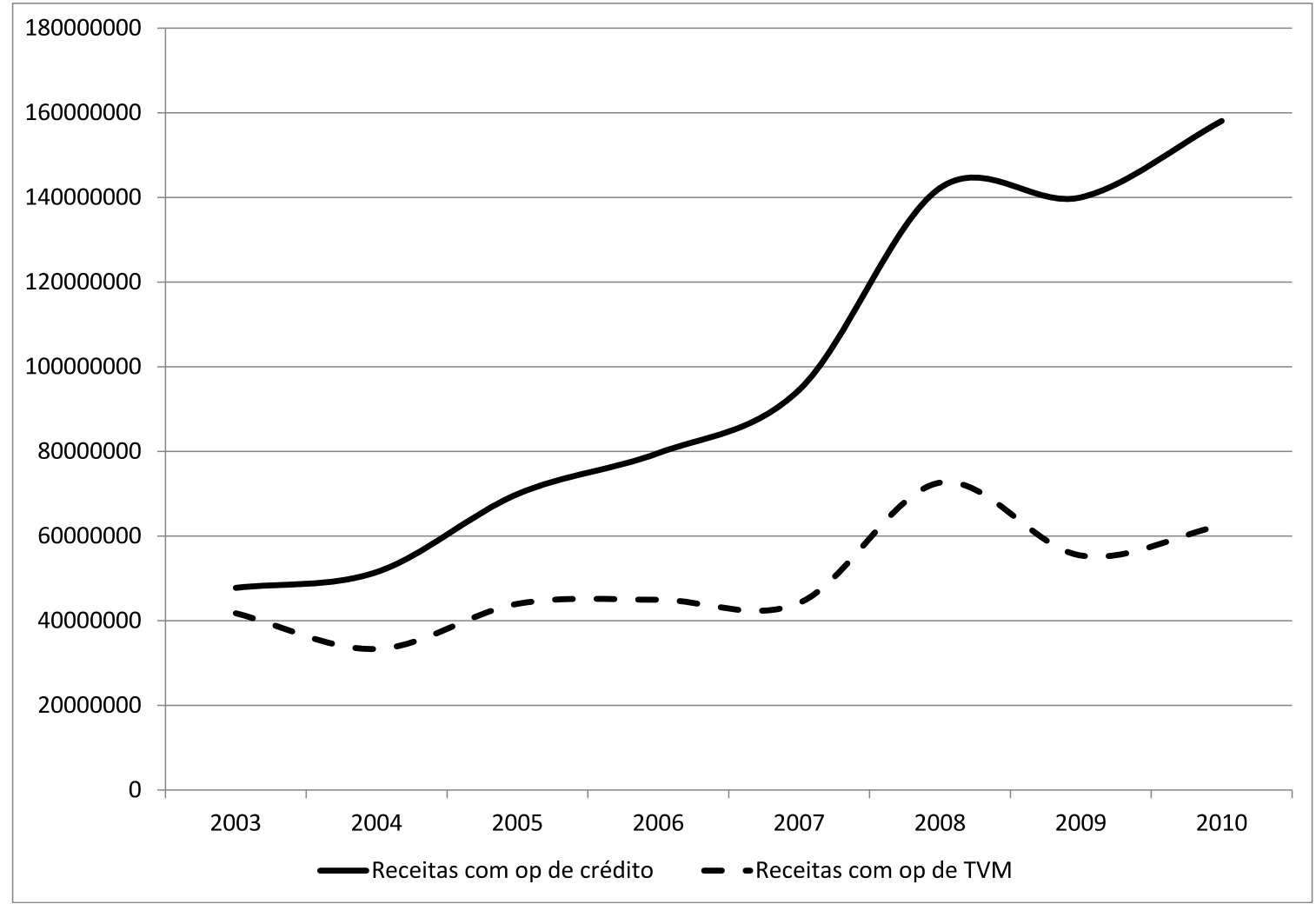

Fonte: Elaboração própria a partir de dados do Banco Central do Brasil.

\section{Comportamento dos Bancos Públicos no Ciclo de Expansão de Crédito}

Evidentemente, a forma através da qual bancos privados e públicos ingressaram no ciclo de expansão de crédito foi diferenciada. Conforme evidenciam os dados do Gráfico 2 e da Tabela 1, o ciclo é iniciado no ano de 2004 pelos bancos privados (nacionais e estrangeiros), e somente no ano de 2005 é que os bancos públicos expandem o crédito mais fortemente. Ainda assim, a taxa de crescimento do crédito a partir dos bancos públicos cresce sempre a taxas inferiores em comparação com a média do SFN e com os bancos privados, notadamente os nacionais. Somente a partir da eclosão da crise financeira mundial de 2008-9 é que as curvas se invertem, com os bancos públicos expandindo as operações de crédito a taxas muito superiores, seja em comparação com a sua média do período anterior, seja em comparação com os bancos privados.

A afirmação acima tem natureza quantitativa, e nada tem a ver com o papel estratégico desenvolvido pelos bancos públicos no Brasil..$^{9}$ Como se sabe, moda-

$9 \quad$ Ver Vidotto (2010). 
lidades específicas de crédito que são cruciais para o desenvolvimento brasileiro são exercidas pelos bancos públicos. ${ }^{10} \mathrm{O}$ financiamento de longo prazo no Brasil é suprido essencialmente pelo Banco Nacional de Desenvolvimento Econômico e Social (BNDES), a partir de recursos de natureza parafiscal do Fundo de Amparo ao Trabalhador (FAT), e do retorno das suas operações de empréstimo e financiamento. ${ }^{11}$ Esta instituição exerce papel crucial ao suprir uma lacuna deixada pelos mercados privados de capitais e pelos bancos privados, cujas operações são essencialmente de médio e curto prazos, ou em volume insuficiente para financiar o investimento. $\mathrm{O}$ financiamento rural, não obstante regulamentação específica que destina $25 \%$ dos depósitos à vista e $40 \%$ da poupança rural para esta modalidade, tem no Banco do Brasil a principal fonte supridora de recursos. Regulamentação específica também obriga que $65 \%$ dos depósitos da caderneta de poupança sejam destinados ao financiamento habitacional, qualquer que seja a propriedade de capital da instituição financeira, e ainda assim a Caixa Econômica Federal (CEF) constitui a principal instituição a atuar neste segmento. Por fim, no que respeita ao desenvolvimento regional/local, são públicas as instituições constituídas para este fim: dois bancos públicos federais possuem atuação regional, Banco da Amazônia (BASA) voltado para a Região Norte; e o Banco do Nordeste do Brasil (BNB); um banco regional de desenvolvimento para os estados da Região Sul de propriedade dos três estados daquela região, Banco Regional de Desenvolvimento do Extremo Sul (BRDE); dois bancos estaduais de desenvolvimento, Banco de Desenvolvimento de Minas Gerais (BDMG) e Banco de Desenvolvimento do Espírito Santo (BANDES); e 14 agências estaduais de fomento.

A despeito da natureza estratégica exercida pelos bancos públicos no Brasil, estes desempenharam um papel durante o ciclo de expansão de crédito o qual, do ponto de vista quantitativo, merece ser melhor detalhado. A hipótese central deste trabalho é que o grau de preferência pela liquidez dos bancos públicos foi, durante os anos de 2003 a 2008, maior do que o dos bancos privados.

A mensuração do grau de preferência pela liquidez dos bancos pode ser feita através de alguns indicadores que podem ser obtidos a partir da composição patrimonial dos bancos. Pelo lado do passivo, proporção mais elevadas dos depósitos a prazo revelam condições melhores para que a instituição financeira aloque seu portfólio em ativos de maior prazo de maturidade, como as operações de crédito. ${ }^{12}$ As proporções menores de depósitos à vista também podem sinalizar na mesma direção, muito embora esta modalidade de depósitos também esteja associada a condições de preferência pela liquidez por parte do público. Já pelo lado

10 Para uma discussão qualitativa a respeito dos bancos públicos no período recente, ver Araujo e Cintra (2010).

11 E, mais recentemente, de recursos oriundos de empréstimos do Tesouro Nacional.

12 Alguns desses indicadores podem ser mais bem percebidos em Cavalcante, Crocco e Jayme Júnior (2004). 
do ativo, menores proporções de operações com TVM e derivativos são indicadores de menor preferência por ativos líquidos, em prol de operações de crédito.

Cabe ainda uma importante observação metodológica para a leitura das tabelas a seguir. Enquanto a seção anterior fez um panorama geral a respeito do ciclo expansivo de crédito no Brasil considerando a totalidade do SFN, a presente seção apresentará estatísticas considerando somente o assim chamado Consolidado Bancário I, definido pelo Banco Central como instituições financeiras do tipo comercial, banco múltiplo com carteira comercial ou caixa econômica. Este segmento é representativo do SFN, respondendo, em outubro de 2010 , por $86 \%$ dos ativos totais e por $85 \%$ das operações de crédito e arrendamento mercantil. Esta distinção se faz necessária porque os demais conceitos utilizados pelo Banco Central (consolidados bancários II, III e IV e consolidado não bancário) não possuem as características da firma bancária tradicional: por não captarem depósitos à vista, a sua inclusão nas estatísticas tende a oferecer interpretações distorcidas a respeito do grau de preferência pela liquidez do conjunto de bancos públicos versus privados a partir da composição do passivo e do ativo. ${ }^{13}$ Estas, por suas vezes, são feitas segundo a seguinte tipologia: bancos públicos (federais e estaduais) e bancos privados (de controle nacional, de controle estrangeiro e privado com participação estrangeira. A agregação se dá por soma simples das contas do ativo e do passivo, de modo a assegurar que as médias apresentadas são ponderadas.

As Tabelas 2 e 3 apresentadas a seguir, quando lidas em conjunto, permitem perceber que a expansão das operações de crédito a partir do ano de 2004 levou o conjunto do sistema bancário brasileiro ${ }^{14}$ a administrar seu passivo de tal sorte a elevar as captações de recursos sob a forma de depósitos a prazo. Esta estratégia foi mais intensificada pelo conjunto dos bancos privados nos anos iniciais do ciclo expansivo de crédito, até o ano de 2005, quando estes reveem suas estratégias. $\mathrm{Ou}$, em outras palavras, a preferência pela liquidez dos bancos públicos, quando medida por este critério, foi maior do que a dos bancos privados até o ano de 2005, quando a posição se inverte, não por um comportamento mais agressivo por parte dos bancos públicos, mas sim devido a um maior conservadorismo por parte dos bancos privados. A inflexão ocorrida no ano de 2005 está muito provavelmente associada ao ciclo de expansão da taxa básica de juros implementada pelo Comitê de Política Monetária (Copom) do Banco Central já no ano anterior. As maiores quedas dos depósitos a prazo como proporção do passivo, contudo, ocorrem no ano de 2007, quando o Copom já havia reiniciado o afrouxamento da

13 O BNDES sozinho, por exemplo, detém mais de $11 \%$ dos ativos totais do SFN, e igual proporção do estoque de crédito. Ademais, pela natureza desta instituição, não se aplica estritamente a lógica descrita na seção 2 no que diz respeito às motivações para concessão de crédito, tampouco é capaz de emitir a totalidade das suas obrigações.

14 Estamos nos referindo ao Consolidado Bancário I. 
política monetária, e ocorrem em função da estratégia de três instituições privadas que naquele ano registraram redução somada de mais de $R \$ 15$ bilhões na rubrica de depósitos a prazo. ${ }^{15}$ Já no ano seguinte, os depósitos a prazo como proporção do passivo voltam a crescer, atingindo o patamar de quase $24 \%$, e já sem distinção relevante entre bancos públicos e privados.

15 ABN-Amro, Votorantim e Safra. 


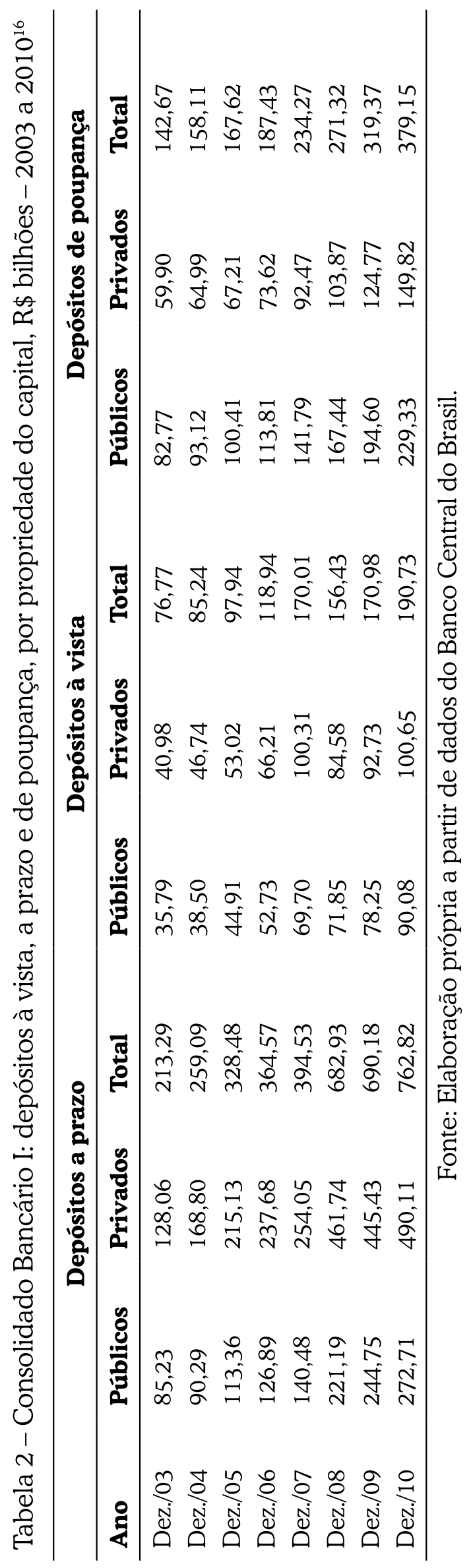

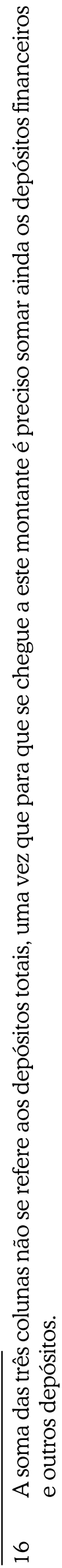




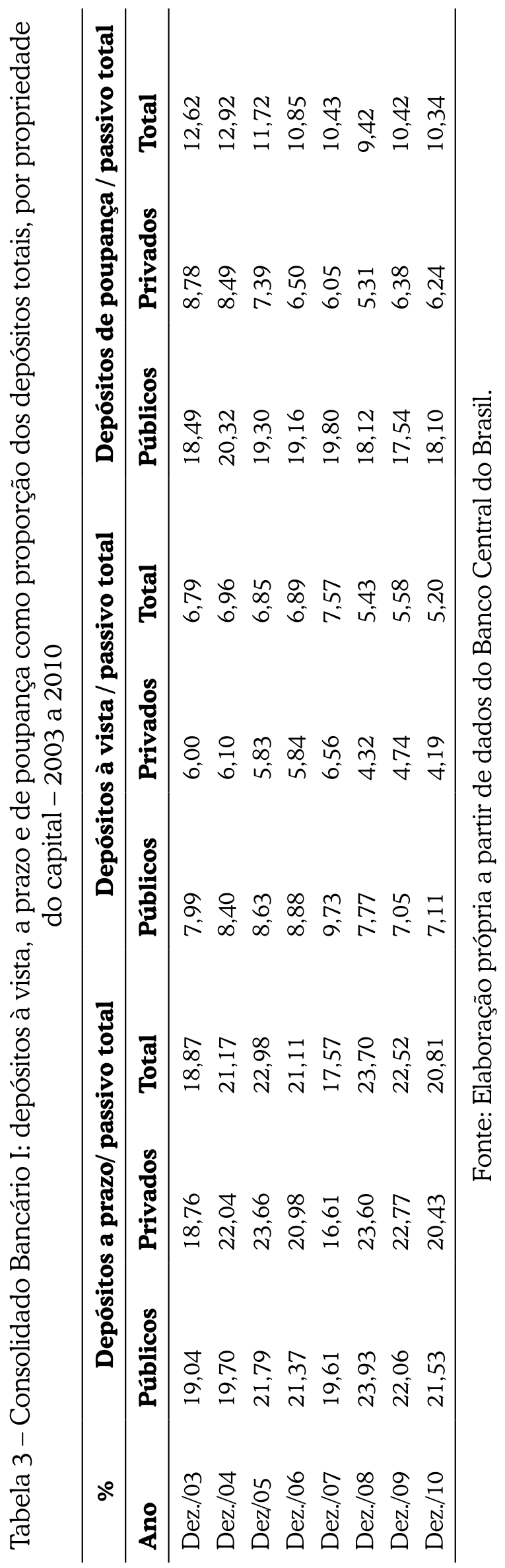


As demais colunas da tabela (depósitos à vista e depósitos de poupança como proporção do passivo total) não necessariamente revelam o grau de preferência pela liquidez dos bancos. O primeiro indicador revela, na verdade, a preferência do público pela manutenção de ativos sob a forma mais líquida. Já o segundo indicador, embora diga respeito a recursos de prazo mais longo, está associado a uma modalidade de crédito específica, que é o imobiliário. Entretanto, a composição dos depósitos de uma instituição evidencia a administração dinâmica do seu passivo: a maior exposição ao crédito os induz a privilegiar obrigações com prazos de maturação mais alongados (OLIVEIRA, 2006).

A análise da composição dos ativos, por sua vez, tende a apontar na mesma direção, qual seja, de um maior conservadorismo por parte dos bancos públicos desde o início do ciclo de expansão de crédito até a eclosão da crise financeira internacional. De acordo com os dados da Tabela 4, a participação das operações de TVM e derivativos vem caindo para o conjunto do consolidado bancário I desde o ano de 2003. O menor comprometimento das operações ativas com TVM e derivativos revela a opção por ativos menos líquidos no portfólio das instituições em questão e engendra, em um primeiro momento, a uma conclusão aparentemente óbvia: a queda na taxa básica de juros ocorrida entre 2003 e 2010 teria induzido os bancos a expandir suas operações de crédito. Os dados da Tabela 4 corroboram essa hipótese apenas parcialmente, uma vez que o crescimento da relação operações de crédito/ativos totais é menos que proporcional à queda da relação TVM e derivativos/ ativos totais. 


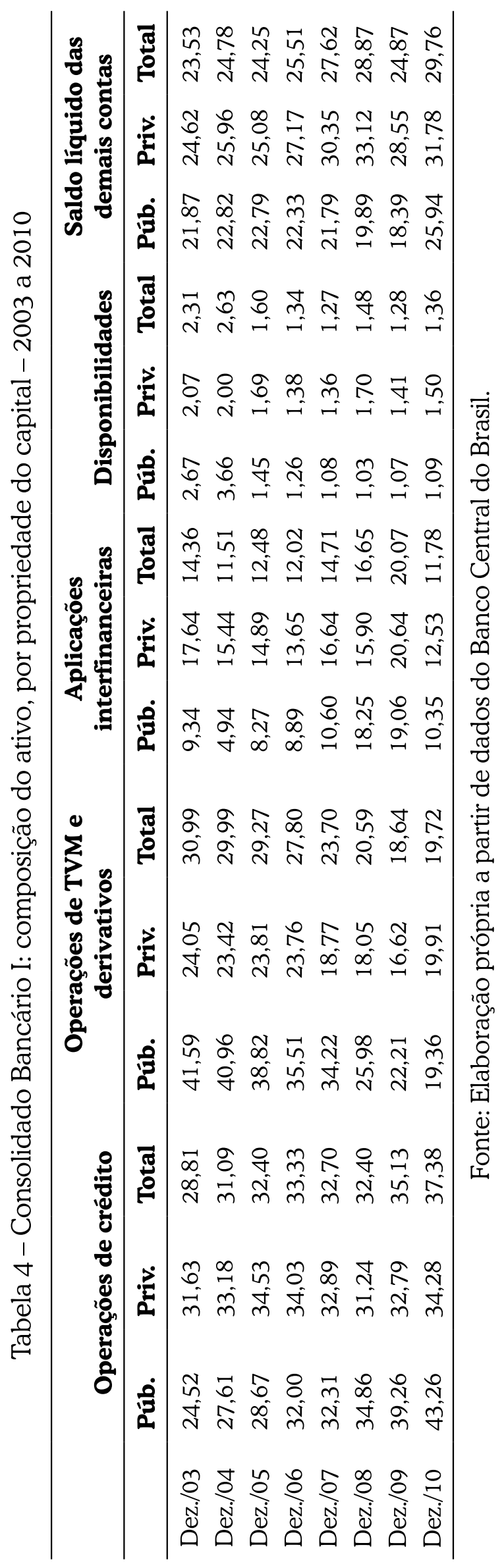


Por outro lado, a Tabela 4 também revela que as aplicações interfinanceiras, outra modalidade através da qual os bancos podem manter seus ativos sob uma forma mais líquida, descrevem tendência de alta para o conjunto do consolidado bancário I. Ou, em outras palavras, vale dizer que a queda na taxa básica de juros induziu o setor bancário a recompor seu portfólio tendo as operações de crédito como uma das opções, não necessariamente preferencial.

Novamente, bancos públicos e privados tiveram um comportamento distinto durante o período. A proporção TVM e derivativos/ativos totais permanece superior para o conjunto dos bancos públicos durante quase todo o período, e a queda durante os três primeiros anos ocorre de forma bastante gradual, evidenciando não só um grau mais elevado de preferência pela liquidez, como também uma resistência à queda, a qual somente será mais intensa a partir de 2008. Esta queda mais intensa permite que, já no ano de 2010, o indicador para os bancos públicos convirja para o dos bancos privados - até pelo aumento em mais de três pontos percentuais registrado no ano de 2010. A convergência, contudo, ocorre muito mais por força do maior conservadorismo registrado pelos bancos privados no ano de 2010, quando a proporção de TVM se eleva em mais de três pontos percentuais.

Os recursos "liberados", ou não utilizados, na aquisição de TVM foram mais intensamente realocados em operações de crédito por parte dos bancos públicos do que pelos bancos privados: de fato, a relação operações de crédito/ativos totais cresce de forma mais robusta entre os primeiros. Evidentemente, a base para os bancos públicos era inferior, havendo mais espaço para expansão deste indicador.

A expansão da participação das operações interfinanceiras também é mais intensa entre os bancos públicos. Neste quesito, é possível verificar uma situação oposta à proporção de TVM e derivativos: no início do ciclo expansivo de crédito, eram os bancos privados quem mantinham proporções maiores de seus ativos sob a forma de operações interfinanceiras, e os bancos públicos descreveram uma indesejável trajetória de convergência para este padrão.

Considerando-se que, pelo lado do ativo, a proporção de TVM e derivativos somada à proporção de aplicações interfinanceiras constitui uma boa proxy para medir a preferência pela liquidez dos bancos é fácil perceber que durante todo o ciclo de expansão de crédito os bancos públicos revelaram grau de preferência pela liquidez superior à dos bancos privados. A convergência ocorre somente após a eclosão da crise financeira internacional, quando a preferência pela liquidez dos bancos privados se eleva, enquanto a dos bancos públicos se contrai de forma mais intensa. A inversão de posição ocorre somente no ano de 2010. O Gráfico 5 sintetiza esta relação. 
Gráfico 5 - Consolidado Bancário I: TVM e derivativos + aplicações interfinanceiras como proporção do ativo - 2003 a 2010

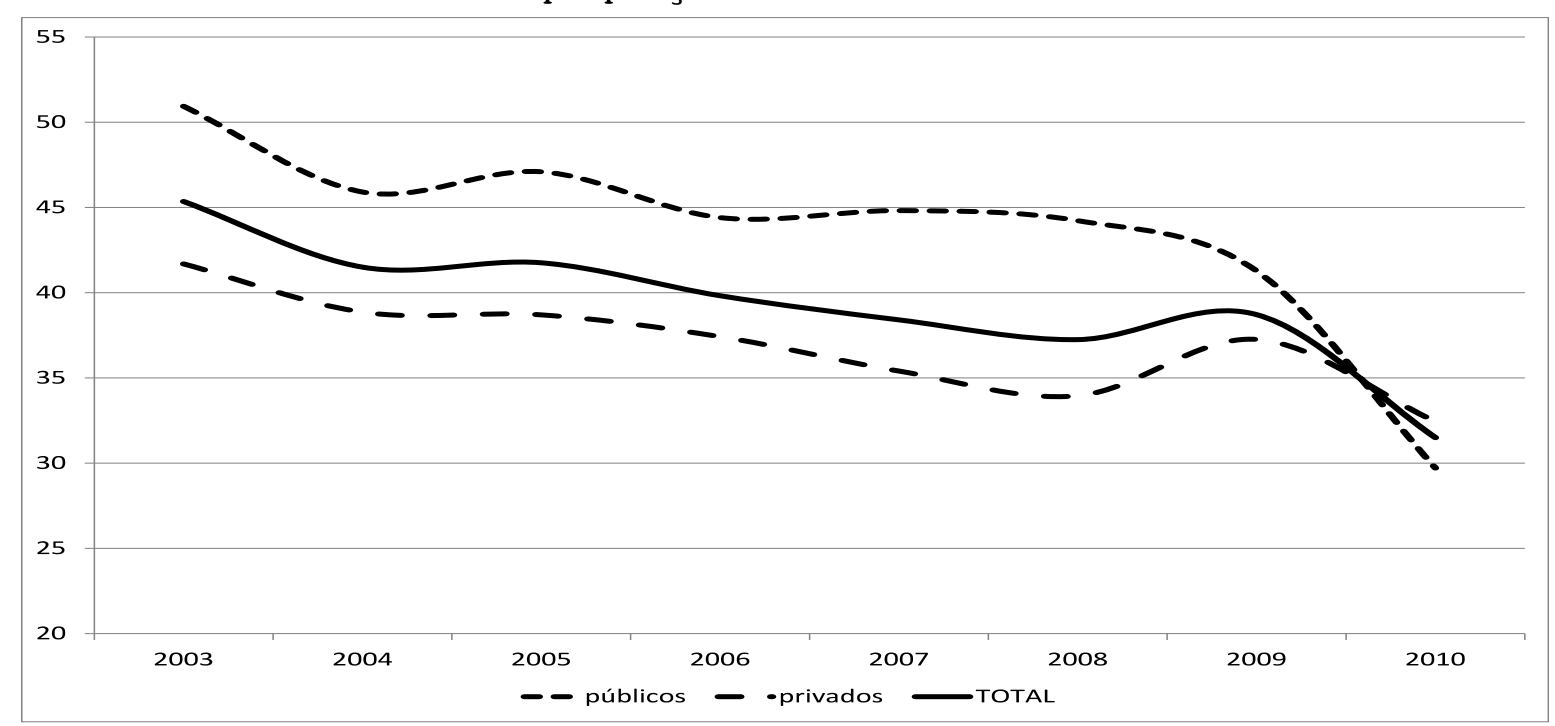

Fonte: Elaboração própria a partir de dados do Banco Central do Brasil.

Este comportamento relativamente conservador por parte dos bancos públicos pode ser explicado pela prioridade em obtenção de resultados econômico-financeiros, notadamente por meio de uma estratégia de composição da carteira de ativos composta prioritariamente por títulos públicos. De fato, nos anos iniciais do ciclo expansivo de crédito até o ano de 2005, as receitas obtidas pelos bancos públicos com operações de TVM eram superiores às receitas com operações de crédito e arrendamento mercantil (Tabela 5), ao passo que para os bancos privados as receitas com essas últimas eram sistematicamente maiores. $\mathrm{O}$ ano de 2009 representou um divisor de águas: as receitas totais com operações de intermediação financeira caem para o conjunto do consolidado bancário I, qualquer que seja a propriedade do capital. Entretanto, as receitas com operações de crédito e arrendamento mercantil por parte dos bancos públicos sobem, e caem por parte dos bancos privados. Os dados contrariam críticas feitas à ação anticíclica implementada pelos bancos públicos após a crise financeira de 2008-9, segundo as quais a qualidade dos ativos dessas instituições sofreria deterioração com ônus para o Tesouro Nacional, que teria de arcar com essas perdas (PINHEIRO, 2009). 


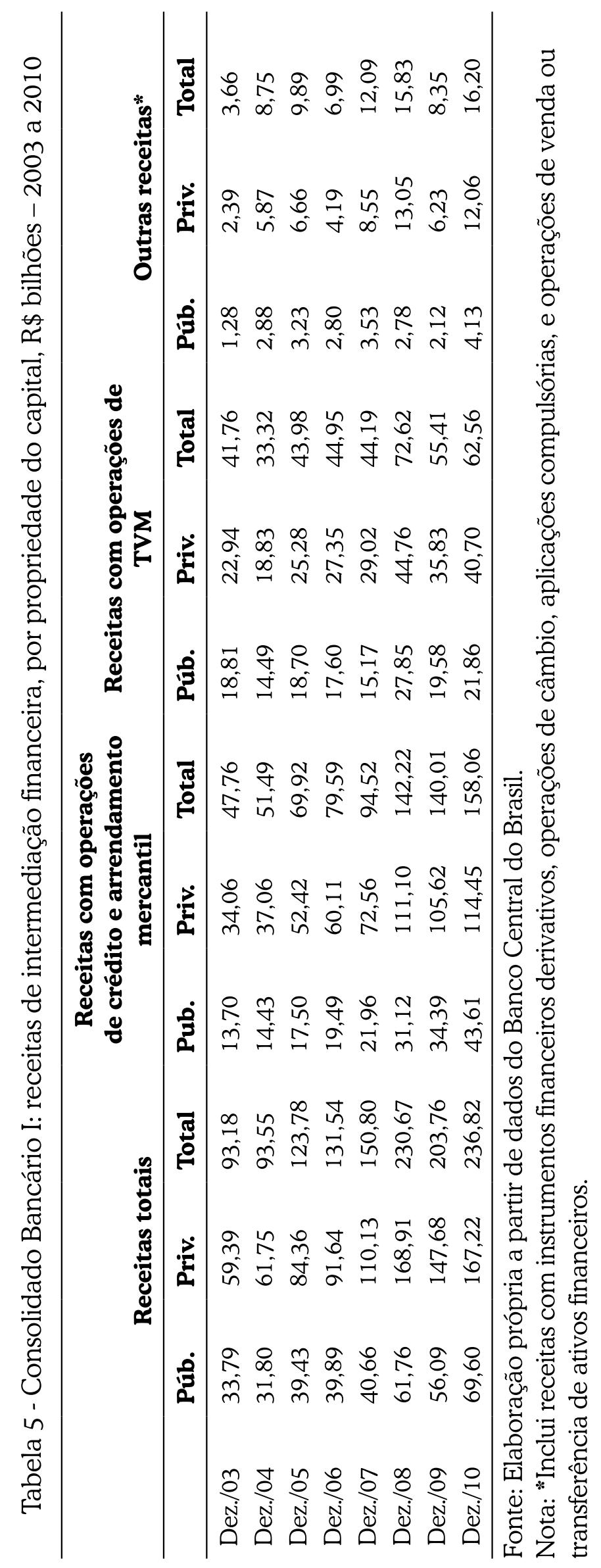


A análise da composição das receitas, apresentada na Tabela 6, permite outras conclusões. Verifica-se, de fato, uma queda expressiva das receitas com operações de TVM em favor das receitas com operações de crédito e arrendamento mercantil para o consolidado bancário I, em consonância com a hipótese segundo a qual a queda da taxa básica de juros teria sido uma das causas do ciclo expansivo de crédito. A queda proporcional das receitas com TVM ocorre tanto para os bancos públicos como para os bancos privados. Duas coisas chamam a atenção nesta comparação. A primeira delas é que a queda é contínua para os bancos privados e descontínua para os bancos públicos, evidenciando o conservadorismo na estratégia implementada por estes últimos (em especial no ano de 2008). A segunda é que, na composição das receitas dos bancos públicos, a participação das operações de TVM é consistentemente mais elevada quando comparado com os bancos privados, embora a diferença diminua ao longo do período considerado. 


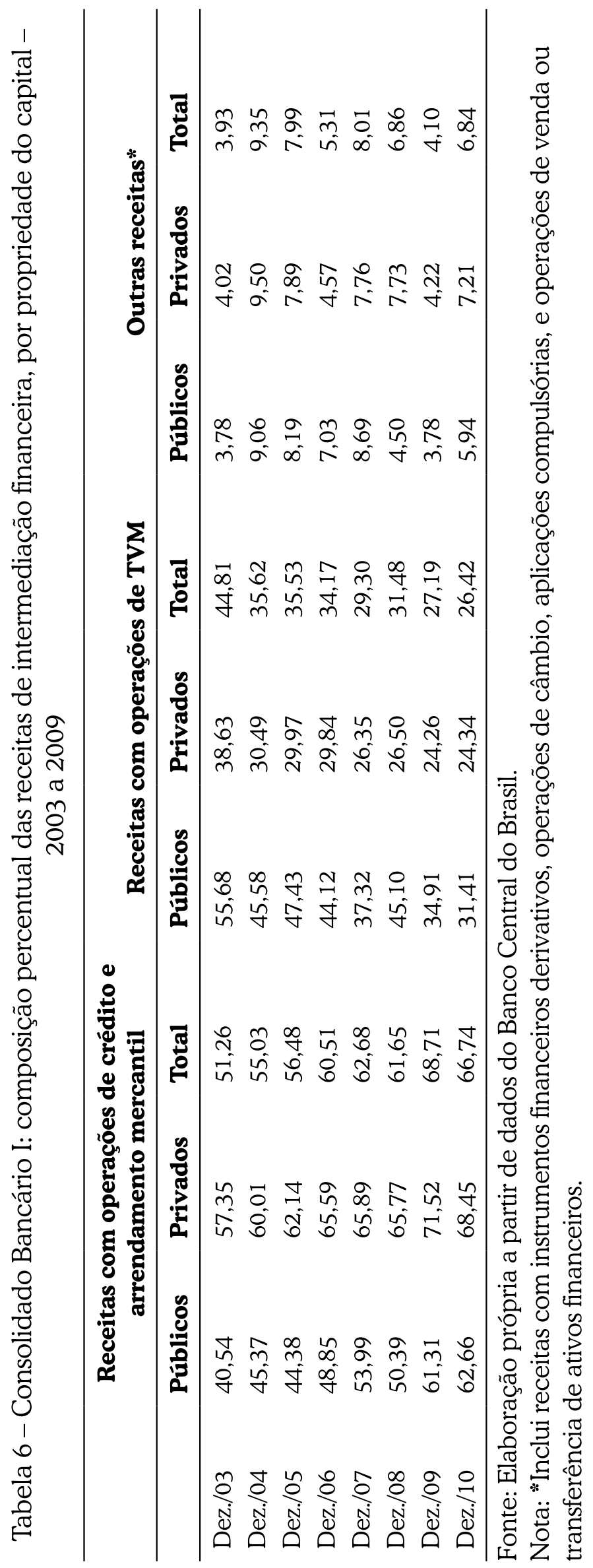


O Gráfico 6 reforça o argumento anterior ao apresentar a relação entre receitas com operações financeiras de TVM e receitas com operações de crédito, para a média dos bancos e também conforme o controle de capital. A partir de 2003, esta relação é sempre decrescente para os bancos privados (incluindo os bancos estrangeiros), ao passo que para os bancos públicos o indicador declina em 2004, volta a subir em 2005 e somente passa a cair com consistência a partir do ano seguinte, permanecendo, contudo, sempre acima dos bancos privados.

Gráfico 6 - Consolidado bancário I: relação entre receitas com operações de TVM/ receitas com operações de crédito e arrendamento mercantil, por controle de capital

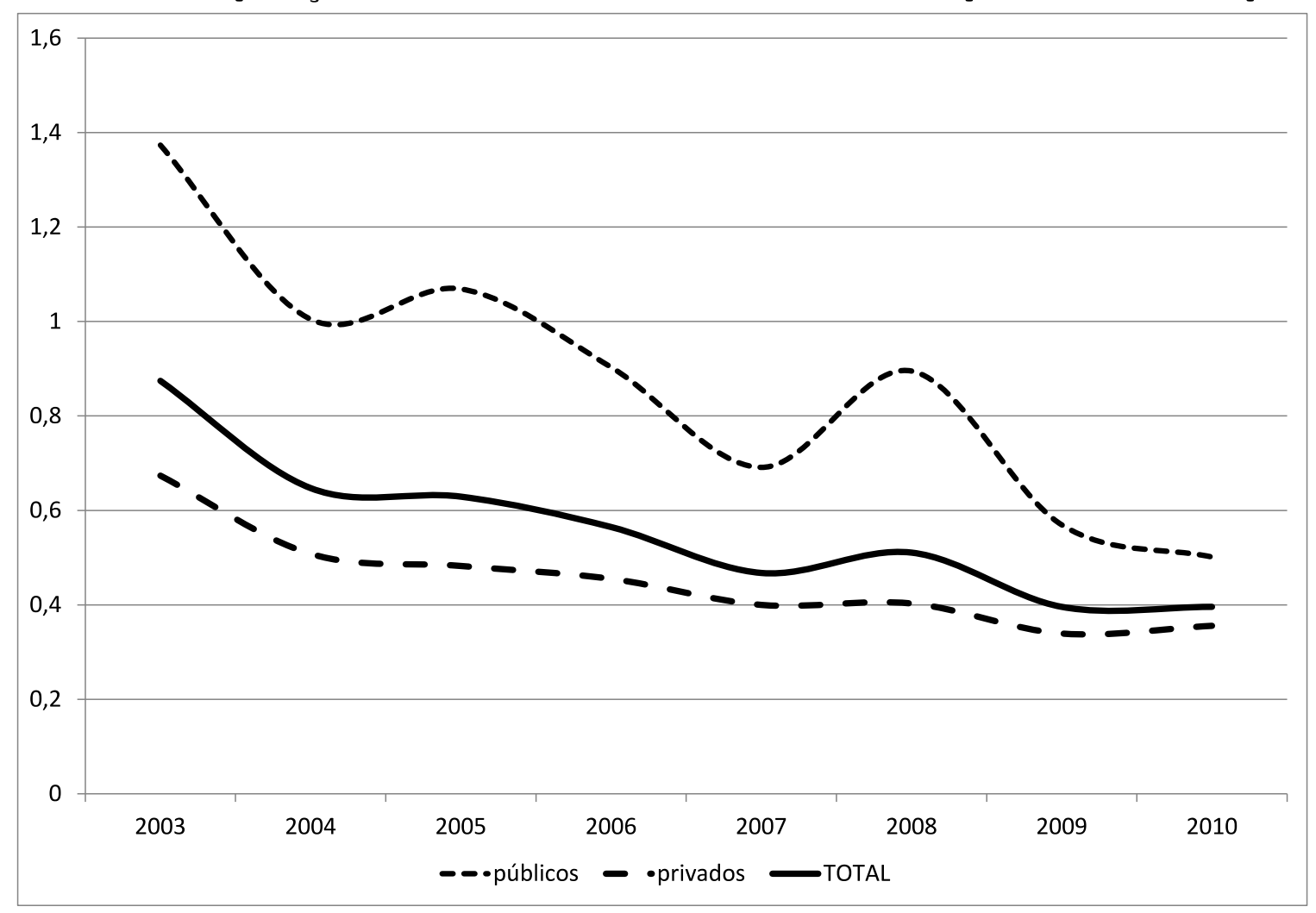

Fonte: Elaboração própria a partir de dados do Banco Central do Brasil.

Também chama a atenção na Tabela 6 o fato de que a participação das receitas com operações de crédito e arrendamento mercantil para os bancos privados seja bem mais elevada quando comparada com os bancos públicos. Neste sentido, os dados não espelham o que seria de se esperar a partir da análise dos dados da Tabela 4. A partir de 2008, a composição do ativo dos bancos públicos torna-se mais favorável às operações de crédito do que para os bancos privados, ao contrário do que prevalecia até então. No entanto, as receitas dos bancos públicos com essas operações têm sido, em termos proporcionais, sistematicamente mais baixas do que para os bancos privados. A resposta provavelmente passa pela qualidade das operações de crédito, o que se reflete na sua rentabilidade. Os Gráficos 7 e 8 mostram a receita obtida para cada $R \$ 1$ aplicado em 
operações de crédito e arrendamento mercantil, bem como com TVM e derivativos. O gap entre bancos públicos e privados é bem maior para as operações de crédito do que para as operações com TVM, o que sinaliza:

a) a qualidade das operações de crédito dos bancos públicos pode ser inferior a dos bancos privados; $\mathrm{e}$

b) a busca por resultados econômico-financeiros tem norteado a atuação dos bancos públicos a ponto da rentabilidade da sua carteira de ativos financeiros ser semelhante à dos bancos privados.

Em particular após a crise financeira, os bancos públicos procuraram compensar ganhos menores advindos das operações de crédito com ganhos maiores advindos das operações com TVM. Esses dados, antes de servirem como críticas à sabidamente importante atuação dos bancos públicos no processo de recuperação da economia brasileira durante o biênio 2009-10, devem lançar luz à reflexão a respeito da dicotomia entre cumprimento das funções clássicas do banco público versus necessidade de obtenção de resultados econômico-financeiros.

Gráfico 7 - Consolidado Bancário I: relação entre receitas com operações de crédito e arrendamento mercantil / operações de crédito e arrendamento mercantil, por propriedade do capital - 2003 a 2010

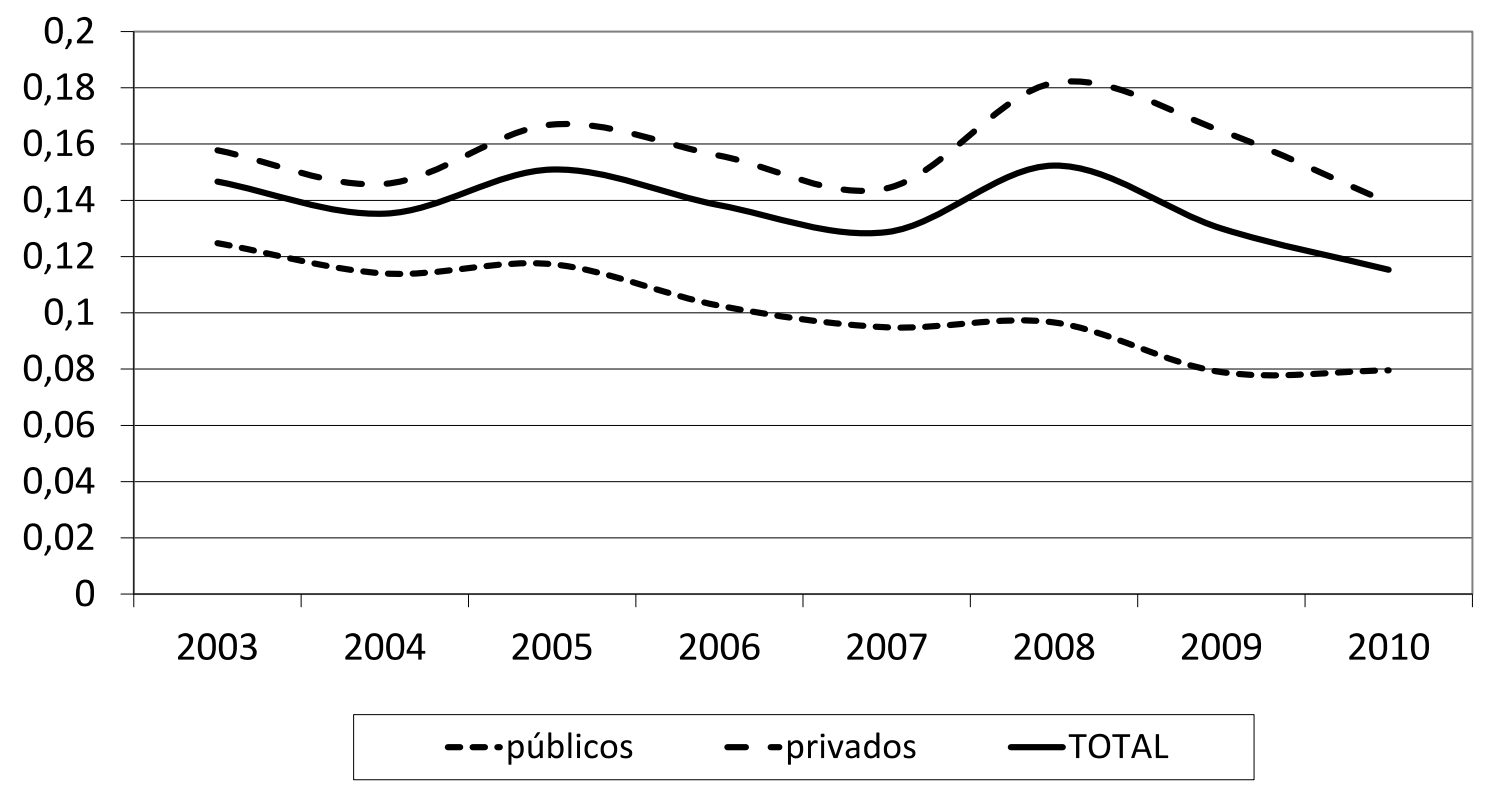

Fonte: Elaboração própria a partir de dados do Banco Central do Brasil. 
Gráfico 8 - Consolidado Bancário I: relação entre receitas com operações de TVM / operações de TVM, por propriedade do capital - 2003 a 2010

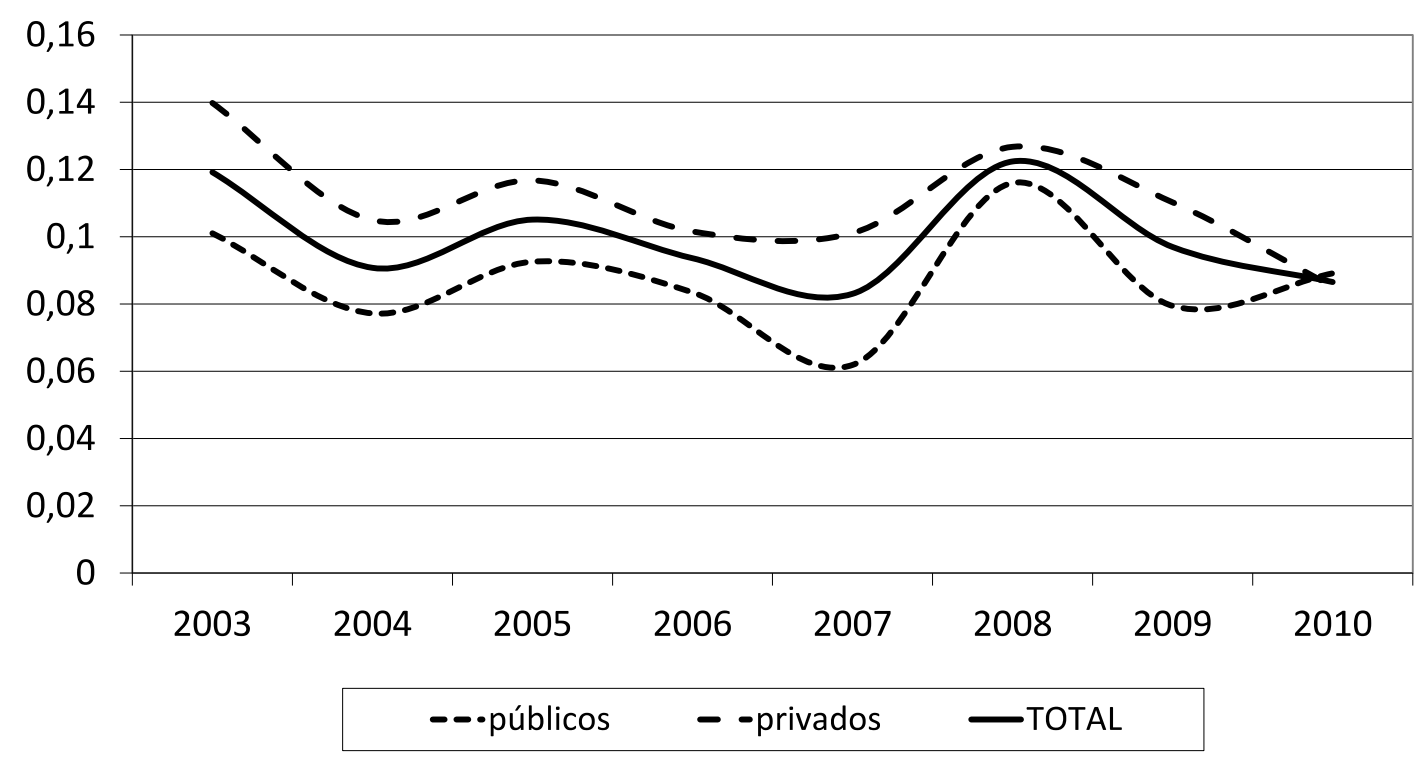

Fonte: Elaboração própria a partir de dados do Banco Central do Brasil.

\section{Considerações Finais}

O conceito de preferência pela liquidez é útil para o entendimento do ciclo de expansão do crédito ocorrido no Brasil nos últimos anos. De fato, os indicadores que são utilizados como proxy da preferência pela liquidez apontam para uma queda quase contínua, resultando na expansão das operações de crédito e na recomposição do portfólio do sistema bancário brasileiro. Pode-se afirmar, de modo geral, que a redução da rentabilidade dos ativos financeiros e o cenário macroeconômico menos incerto contribuíram para que o trade-off entre retorno esperado e preferência pela liquidez das diferentes classes de ativos foi favorável ao crescimento das operações de crédito.

A reversão do estado de confiança após a eclosão da crise financeira de 2008 trouxe consigo um aumento da preferência pela liquidez do setor bancário privado, e a atuação dos bancos públicos foi decisiva para contra-arrestar os efeitos da contração de crédito resultante deste comportamento.

A propósito, a desagregação dos indicadores segundo a propriedade da instituição bancária revela que a redução da preferência pela liquidez foi um comportamento que atingiu tanto os bancos privados como os bancos públicos. Entretanto, chama a atenção o fato destes últimos terem uma atuação sistematicamente mais conservadora do que os bancos privados até a eclosão da crise financeira. Movidos pela necessidade de obtenção de resultados econômico-financeiros, essas instituições não foram capazes de interpretar o ambiente macroeconômico como favorável para reduzir suas posições em ativos mais líquidos em prol das 
operações de crédito e arrendamento mercantil, tal como fizeram as instituições de capital privado. Os dados apresentados sugerem que os bancos públicos não só registraram um grau de preferência pela liquidez em geral superior à dos bancos privados, como também sugerem resistência à queda até a crise financeira. Os bancos públicos entraram com um retardo de dois anos no ciclo de expansão de crédito, e ainda assim exibindo indicadores em geral menos pujantes do que os exibidos pelos bancos privados.

Esses dados devem ser lidos em um contexto maior, em que os bancos públicos defrontam-se com um permanente dilema entre o cumprimento de suas funções clássicas (fomento setorial, regional e atuação anticíclica) versus a necessidade de obtenção de resultados econômico-financeiros. Entre 2003 e 2008, a necessidade de resultados parece ter funcionado como restrição à atuação dos bancos públicos, não obstante o crédito oriundo dessas instituições também ter sofrido expansão, e a despeito dos aspectos qualitativos associados à atuação dos bancos públicos. Aparentemente, a equação parece ter sido melhor equilibrada após a crise financeira, quando os bancos públicos expandiram suas operações de crédito e ainda assim exibiram resultados comparáveis aos bancos privados.

\section{Referências}

ARAUJO, V. L.; CINTRA. M. A. M. O papel dos bancos públicos federais na economia brasileira. In: CARDOSO JUNIOR, J. C. (Org.). Estado, instituições e democracia: desenvolvimento. Brasilia: IPEA, 2010. (Perspectivas do desenvolvimento brasileiro, v. 9, pt. 3).

BARROS, J. P. O.; FAGUNDES, M. E. M.; CAVALCANTE, L. R. Spread bancário em operações de crédito consignado no Brasil. Revista Desenbahia, Salvador, n. 7, p. 65-85, set. 2007.

CAETITÉ, A. N.; STRACHMAN, E.; COSTA, G. R. B. Convenções, preferência pela liquidez e volume de crédito bancário no Brasil, no período 1996-2008. In: ENCONTRO INTERNACIONAL DA ASSOCIAÇÃO KEYNESIANA BRASILEIRA, 2., 2009, Porto Alegre. O dossiê da crise. Porto Alegre: AKB, 2009.

CARVALHO, F. C. et al. Economia monetária e financeira: teoria e política. Rio de Janeiro: Elsevier, 2000.

Sobre a preferência pela liquidez dos bancos. In: PAULA, L. F.; OREIRO, J. L. Sistema financeiro: uma análise do setor bancário brasileiro. Rio de Janeiro: Campus, 2007.

CAVALCANTE, A.; CROCCO, M.; JAYME JUNIOR, F. J. Preferência pela liquidez, sistema bancário e disponibilidade de crédito regional. Belo Horizonte: UFMG/CEDEPLAR, 2004. (Texto para Discussão, n. 237).

DEOS, S.; MENDONÇA, A. R. R. Uma proposta de delimitação conceitual de bancos públicos. In: JAYME JUNIOR, F. J.; CROCCO, M. Bancos públicos e desenvolvimento. Brasília: IPEA, 2010.

FREITAS, M. C. P.; PRATES, C. O mercado de crédito no Brasil: tendências recentes. In: BIASOTO JUNIOR, G., NOVAIS, L. F.; FREITAS, M. C. P. Panorama das economias internacional e brasileira: dinâmica e impactos da crise global. São Paulo: FUNDAP, 2009. 
GURLEY, J. G.; SHAW, E. S. Financial aspects of economic development. The American Economic Review, Nashville, v. 55, n. 4, p. 515-538, Sept. 1955.

HERMANN, J. Bancos públicos em sistemas financeiros maduros: perspectivas teóricas e desafios para os países em desenvolvimento. In: ENCONTRO INTERNACIONAL DA ASSOCIAÇÃO KEYNESIANA BRASILEIRA, 2., 2009, Porto Alegre. O dossiê da crise. Porto Alegre: $\mathrm{AKB}, 2009$.

KALECKI, M. Teoria da dinâmica econômica. 2. ed. São Paulo: Nova Cultural, 1983.

KEYNES, J. M. Teoria geral do emprego, do juro e da moeda. Rio de Janeiro: Fundo de Cultura, 1964.

MCKINNON, R. I. Money e Capital in Economic Development. Washington, D. C.: The Brookings Institution, 1973.

MIGLIOLI, J. Acumulação de capital e demanda efetiva. São Paulo: TAQ, 1981.

OLIVEIRA, G. C. O comportamento recente do crédito e da estrutura patrimonial de grandes bancos no Brasil (2002-2005): uma abordagem pós-keynesiana. 2006. Disponível em: <http:// www.sep.org.br/artigo/1_congresso/_281_2e4db2c8878935b67b52d6513c1b7a94.pdf>.

PAULA, L. F. Teoria da firma bancária. In: LIMA, G. T. et al. Macroeconomia moderna: Keynes e a economia contemporânea. Rio de Janeiro: Campus, 1999.

PINHEIRO, A. C. Bancos públicos: bombeiros na crise ou emprestadores de primeira instância? In: BACHA, E. L.; GOLDFAJN, I. (Org.). Como reagir à crise? Políticas econômicas para o Brasil. Rio de Janeiro: Imago, 2009.

PRATES, D.; BIANCARELI, A. M. Panorama do ciclo de crédito recente: condicionantes e características gerais. Projeto de Estudos sobre as Perspectivas da Indústria Financeira Brasileira e o Papel dos Bancos Públicos. 2009. Disponível em: <http://www.bndes.gov.br/SiteBNDES/ export/sites/default/BNDES_pt/Galerias/Arquivos/empresa/pesquisa/SubprojetoII.2_PIF. pdf $>$. Acesso em: 21 mar. 2011.

PRATES, D. Crédito à indústria. Projeto de estudos sobre as perspectivas da indústria financeira brasileira e o papel dos bancos públicos. Subprojeto Mercado de Crédito Bancário. Campinas: FECAMP, 2009. Disponível em: <http://www.iececon.net/arquivos/Financiamento_Industria.pdf $>$. Acesso em: 21 mar. 2011.

SANT'ANNA, A. A.; BORÇA JUNIOR, G. R.; ARAUJO, P. Q. Mercado de crédito no Brasil: evolução recente e o papel do BNDES (2004-2008). In: FERREIRA, F. M. R.; MEIRELLES, B. B. Ensaios sobre economia financeira. Rio de Janeiro: BNDES, 2009

SHAW, E. S. Financial Deepening in Economic Development. New York: Oxford University Press, 1973.

STIGLITZ, J. The Role of the State in Financial Markets. In: ANNUAL BANK CONFERENCE ON DEVELOPMENT ECONOMICS, 1993, Washington, D.C. Proceedings...Washington, D.C.: World Bank, 1993.

VIDOTTO, C. A. Caráter estratégico dos bancos públicos federais: a experiência brasileira recente. In: JAYME JUNIOR, F. G.; CROCCO, M. Bancos públicos e desenvolvimento. Rio de Janeiro: IPEA, 2010.

Recebido em: 22/09/2011.

Aceito em: 02/07/2012. 